\title{
Dispersal and recruitment of fiddler crab larvae in the Delaware River estuary
}

\author{
C. E. Epifanio, K. T. Little, P. M. Rowe \\ College of Marine Studies, University of Delaware, Lewes, Delaware 19958, USA
}

\begin{abstract}
In spite of a semi-terrestrial adult habitat, fiddler crabs of the Middle Atlantic Bight show no adaptation for retaining larvae in tidal marsh creeks. Abundant data show that newly hatched zoeae are rapidly carried into primary estuaries. The present investigation shows that there is some retention of all zoeal stages within the estuary, but that substantial numbers of zoeae are carried to the adjacent continental shelf. Later zoeal stages are common deep in the water column at stations as far as $35 \mathrm{~km}$ from the bay mouth. Collections over 6 consecutive tidal cycles in a secondary estuary indicate that megalopae utilize flood tidal currents to augment their upstream migration to adult habitat. A conceptual model based on both field and laboratory data predicts that salinity is a gross filter separating populations of Uca minax and Uca pugnax, but that final selection of adult habitat is controlled by other factors.
\end{abstract}

\section{INTRODUCTION}

Among estuarine crabs of the Middle Atlantic Bight (USA), fiddler crabs face perhaps the most extreme risk of transport of larvae away from suitable adult habitat. Two species of fiddler crab are common in the extensive salt marshes bordering Delaware Bay (USA). UCa minax is found in marshy regions of low salinity while Uca pugnax is found in mesohaline regions close to the seawater source (Miller \& Maurer 1973). A third species Uca pugilator occurs only rarely in the Delaware Bay system.

After metamorphosing from the megalopa stage, fiddler crabs have no swimming ability, and the location of metamorphosis probably represents the eventual site of adult existence. In spite of this, there are ample field data showing that Uca larvae are flushed from the marsh environment soon after hatching (Christy \& Stancyk 1982, Lambert \& Epifanio 1982); indeed the spawning cycle of $U_{c a}$ appears to augment this flushing, as larvae are hatched just before nocturnal spring high tides and are carried from the marsh creeks on the ensuing ebb tides (Wheeler 1978). Zoeal development takes place in the lower regions of large estuaries such as the Chesapeake or Delaware (Sandifer 1975, Dittel \& Epifanio 1982) or on the adjacent continental shelf (Christy \& Stancyk 1982). Recruitment to adult popula- tions appears to depend on the transport of megalopae back to the marsh environment (Christy 1982, Meredith 1982), and segregation of $U$. minax and $U$. pugnax into their eventual adult habitats may depend on differential transport of megalopae of each species.

In this article we present results of extensive collections of Uca spp. zoeae and megalopae over consecutive tidal cycles in the mouth of Delaware Bay and in the mouth of an adjacent secondary estuary. We combine these with results of a survey of the abundance of zoeae on the inner continental shelf near Delaware Bay and with results of a laboratory study of larval development of $U$. minax and $U$. pugnax to construct a probable scenario for dispersal and recruitment of $U_{C a}$ spp. larvae in the region.

\section{METHODS}

Consecutive tidal cycles: zoeae. Zoeae were collected at one station in the mouth of Delaware Bay (Fig. 1) from discrete depths using a $0.3 \mathrm{~m}$ ClarkeBumpus Sampler fitted with $243 \mu \mathrm{m}$ (\#6) net. The Clarke-Bumpus Sampler included a device (Heinle 1965) to deflect jellyfish and ctenophores that were common during the sampling period. Tows of $10 \mathrm{~min}$ were taken every 3 h over 2 consecutive tidal cycles 
from depths of $1 \mathrm{~m}$ beneath the surface and $2 \mathrm{~m}$ above the bottom (depth $=23 \mathrm{~m}$ ). Sampling was conducted over a neap-tide period on 6 to 8 August 1980 .

Continental shelf. Uca larvae were collected weekly from late July through mid-September (1982) at 4 stations located every $12 \mathrm{~km}$ along a transect extending $36 \mathrm{~km}$ SE from Cape Henlopen at the mouth of Delaware Bay (Fig. 1). Samples were taken from $1 \mathrm{~m}$

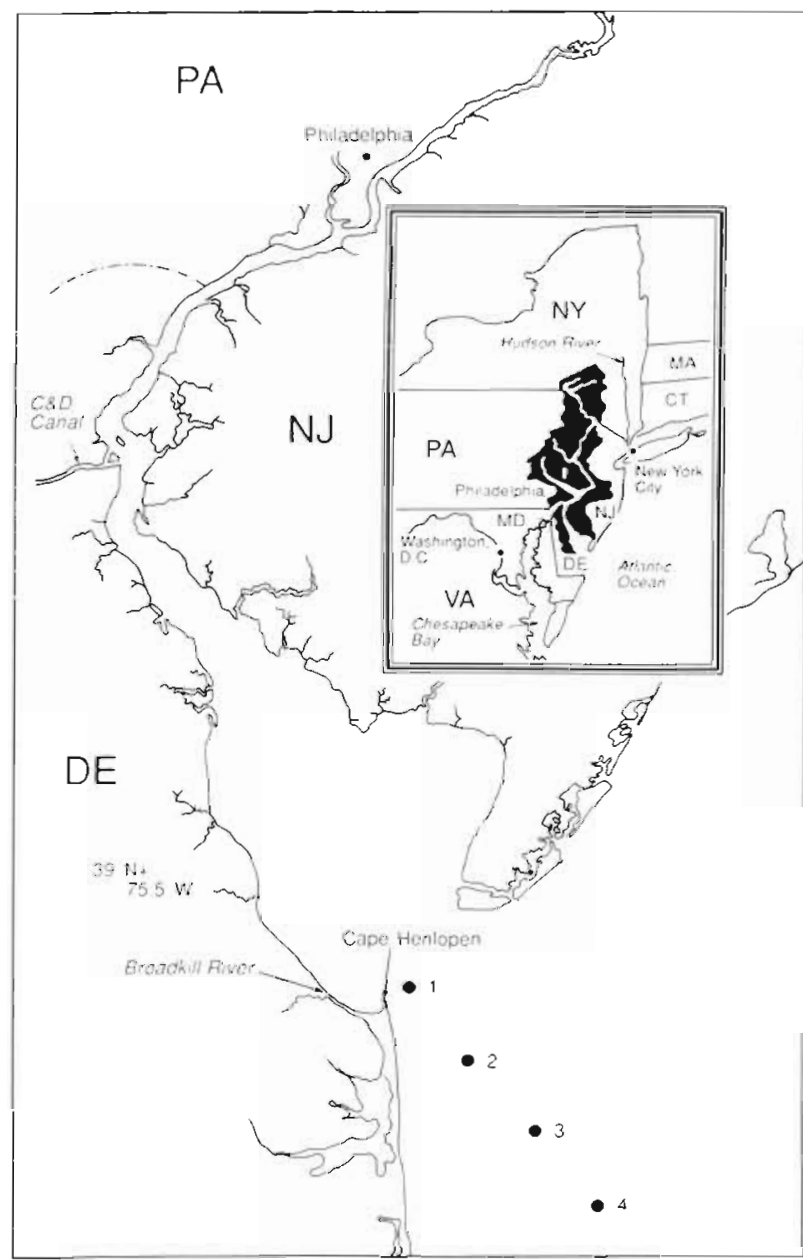

Fig. 1 Location of stations. Abundance of Uca spp. larvae in Delaware Bay system, USA, 1980 to 1985. Transect stations are $12 \mathrm{~km}$ apart

beneath the surface and $1 \mathrm{~m}$ above the bottom using a $0.3 \mathrm{~m}$ Clarke-Bumpus Sampler rigged with $243 \mu \mathrm{m}$ mesh net towed from a $15 \mathrm{~m}$ vessel. An additional sample was taken from the top $0.25 \mathrm{~m}$ at each station using a specially designed neuston sampler (Epifanio et al. 1984),

Consecutive tidal cycles: megalopae. Megalopae were collected at one station in the mouth of the Broadkill River located approximately $5 \mathrm{~km}$ from Cape Hen- lopen at the mouth of Delaware Bay (Fig. 1). Collections were made at a depth of $1 \mathrm{~m}$ beneath the surface (depth of water column varied from 3 to $4 \mathrm{~m}$ depending on tidal stage) with an automated sampler that pumped approximately $0.5 \mathrm{~m}^{3} \mathrm{~min}^{-1}$ through a $243 \mu \mathrm{m}$ mesh net. Sampling was conducted every 2 h over 12 consecutive tidal cycles during a neap-tide period from 6 to 12 September 1985. Each sampling period was $20 \mathrm{~min}$.

General analysis of field samples. Plankton samples were preserved immediately after collection in $4 \%$ formaldehyde and later transferred to $70 \%$ ethanol. Samples were subdivided with a Folsom Plankton Splitter (Dittel \& Epifanio 1982). The number of splits was based on the total volume of plankton collected. One randomly chosen subsample was analyzed for each collection. Larvae were identified to stage using a key to the decapod larvae (Sandifer 1973). However, external morphological characteristics do not allow the separation of $U$. minax and $U$. pugnax zoeae or megalopae. Because the spawning seasons of the 2 species largely overlap in the study area, both species may have occurred in all of our samples.

Larval development. Ovigerous female fiddler crabs were collected in mid-June and late July 1985. The crabs were immediately brought to the laboratory and placed under constant environmental conditions. Larvae of both species were reared at $25^{\circ} \mathrm{C}$ and a photoperiod of 14L:10D; they were fed ad libitum on a diet of rotifers Brachionis plicatilis with the addition of newly hatched brine shrimp Artemia sp. after the eighth day of development. Megalopal diets consisted solely of brine shrimp. Water in the cultures was changed daily, and mortality and stage of development determined. Exuvia and dead larvae were removed daily.

Two experiments were conducted. In Experiment 1, larvae were reared at 10,20 , or $30 \%$ from hatching to crab Stage 1. A total of 150 larvae (50 from each of 3 separate broods) of each species was reared at each salinity. Larvae were reared in $7.5 \mathrm{~cm}$ finger bowls at 10 per bowl. Zoeae of UCa pugnax were not reared at $10 \%$ because results of an earlier investigation showed complete mortality at that salinity (O'Connor \& Epifanio 1985).

In Experiment 2, large numbers of zoeae of each species were reared at $25 \%$ salinity in mass cultures (>100 zoeae per $10.5 \mathrm{~cm}$ finger bowl) until they reached the megalopa stage. A total of 295 Uca pugnax megalopae (approximately equal numbers from each of 5 separate broods) and $285 U$. minax megalopae (approximately equal numbers from each of 6 separate broods) was then transferred to salinities of 10,20 , or $30 \%$ at 5 megalopae per $7.5 \mathrm{~cm}$ finger bowl. Megalopae were acclimated to changing salinity in daily $5 \%$ increments. Mortality and time of development to crab Stage 1 were monitored 


\section{RESULTS}

\section{Consecutive tidal cycles: zoeae}

All 5 zoeal stages were collected at Station 1 in the bay mouth, but zoea Stage I was most abundant. While larvae occurred at both depths throughout the tidal cycle, the abundance of larvae at the surface during flood tides was significantly greater (Mann-Whitney Utest; $\alpha=0.05$ ) than the abundance of larvae at the surface during ebb tides (Table 1). Conversely the abundance of larvae near the bottom during ebb tides

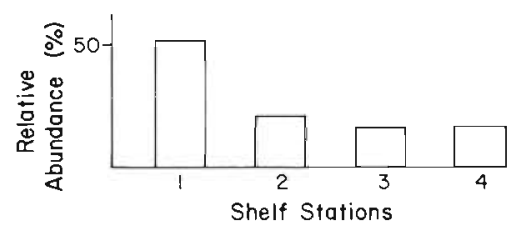

Fig. 2. Uca spp. Percentage abundance of zoea larvae at 4 equidistant stations along a transect extending $36 \mathrm{~km}$ from the mouth of Delaware Bay. Abundance was normalized for sampling effort. Weekly sampling in July-August 1982

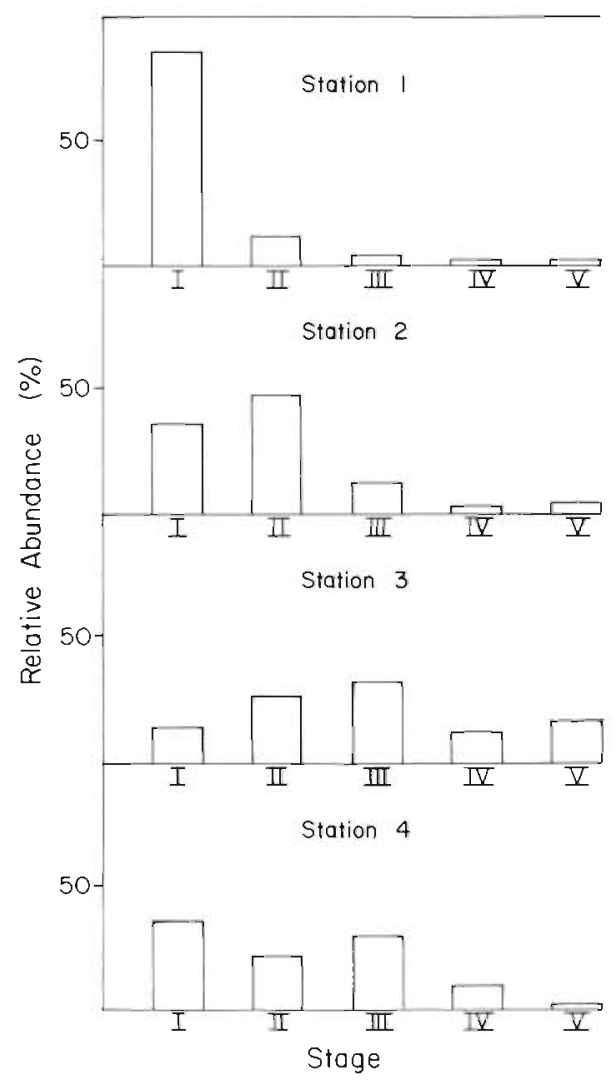

Fig. 3. Uca spp. Relative abundance of each zoeal stage at 4 equidistant stations along a transect extending $36 \mathrm{~km}$ from the mouth of Delaware Bay. Abundance was normalized for sampling effort. Values for each station are percentages of total number of larvae collected at that station. Weekly sampling in July-August 1982 was significantly greater than the abundance at the bottom during flood tides. There was no significant difference in the abundance of zoeae at the surface or near the bottom during daylight or at night.

\section{Continental shelf}

Approximately 11200 Uca spp. larvae were collected during the shelf survey. About $50 \%$ of these occurred at Station 1 in the bay mouth with the remaining $50 \%$ distributed approximately equally among the 3 stations farther offshore (Fig. 2). Zoea Stage I was dominant at Station 1 but more advanced stages made up a greater proportion of the total catch at the 2 stations farthest from the bay mouth (Fig. 3). Less than $10 \%$ of the total catch of zoea Stage I occurred at the 2 offshore stations, while approximately $90 \%$ of the total number of zoea Stages IV and V were collected at these 2 stations (Fig. 4). There was no consistent trend in the relative abundance of larvae collected in the neuston and surface. However, zoea Stages I, II, and III were more abundant in surface collections while an increased proportion of zoea Stages IV and $\mathrm{V}$ were collected in near-bottom water (Fig. 5).

\section{Consecutive tidal cycles: megalopae}

Approximately 3000 Uca spp. megalopae were collected in the mouth of the Broadkill River during a $6 \mathrm{~d}$ period in mid-September 1985. Distinct peaks of abundance were seen during flood-tide periods (Fig. 6), and there was a significant difference (MannWhitney U-test; $\alpha=0.05)$ in the total number of megalopae collected in each tidal phase. Superimposed on this tidal frequency was a diel pattern wherein significantly greater (Mann-Whitney U-test; $\alpha$ $=0.05$ ) megalopal abundance occurred during nocturnal flood tides.

\section{Larval development}

Laboratory duration of the zoeal phase ranged from 14 to $18 \mathrm{~d}$ depending on species and salinity. Salinity had a significant effect (ANOVA; $\alpha=0.05$ ) on survival of zoeae of both species (Table 2). Survival of Uca minax zoeae was approximately equal at 20 and $30 \%$, while maximum survival of $U$. pugnax occurred at $30 \%$. Salinity also had a significant effect (ANOVA; $\alpha$ $=0.05$ ) on survival of the megalopae of both species with maximum survival of $U$. minax at $10 \%$ and of $U$. pugnax at 20 and $30 \%$ (Table 3). Megalopal intermolt duration ranged from 25 to $40 \mathrm{~d}$ depending on salinity 
Fig. 4, Uca spp. Analysis of onshore-offshore gradient in abundance of each zoeal stage at 4 equidistant stations along a transect extending $36 \mathrm{~km}$ from the mouth of Delaware Bay. Abundance was normalized for sampling effort. Values for each zoeal stage are percentages of total number of larvae of that stage collected at all stations. Weekly sampling in JulyAugust 1982

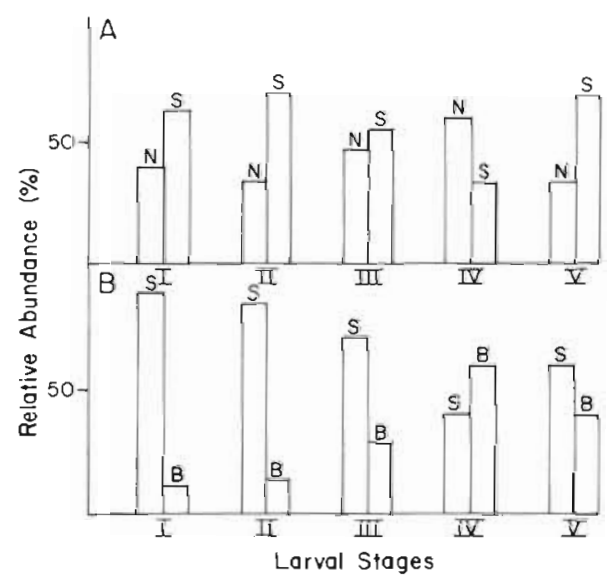

Fig. 5. Uca spp. Relative abundance of each zoeal stage at 3 depths along a transect extending $36 \mathrm{~km}$ from the mouth of Delaware Bay. Abundance was normalized for sampling effort. Values are percentages of total number of zoeae collected at all stations. Weekly sampling in July-August 1982. (A) Comparison of surface and neuston. (B) Comparison of surface and bottom

Table 1. Uca spp. Abundance of zoea larvae collected every $3 \mathrm{~h}$ over 2 consecutive tidal cycles at 1 station in the mouth of Delaware Bay, USA during 6 to 8 August 1980. Water depth $=$ $23 \mathrm{~m}$ at high tide; tidal range $=c a 1 \mathrm{~m}$. Values are mean number of larvae $\mathrm{m}^{-3}$ (1 standard deviation). 'Significant difference $(\alpha=0.05)$ in flood-ebb or day-night values based on Mann-Whitney U-test

\begin{tabular}{|c|c|c|c|c|}
\hline \multirow[t]{2}{*}{ Depth } & \multicolumn{2}{|c|}{ Tidal stage } & \multicolumn{2}{|c|}{ Diel stage } \\
\hline & Flood & $E b b$ & Day & Night \\
\hline Surface & $3.9(3.2)$ & $1.9(0.9)^{\circ}$ & $3.3(3.3)$ & $2.1(1.2)$ \\
\hline Bottom & $1.9(2.9)$ & $3.8(5.5)^{\bullet}$ & $3.3(5.6)$ & $2.1(0.6)$ \\
\hline
\end{tabular}

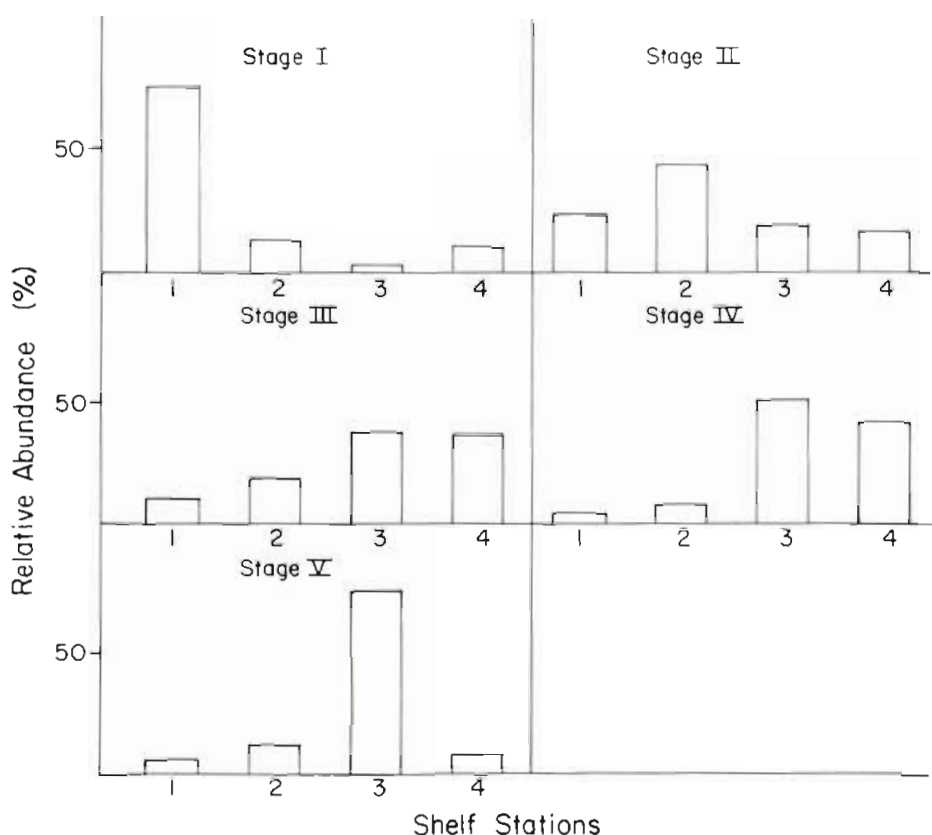

and species. This was more protracted than the intermolt period reported in earlier studies (Wheeler 1978, O'Connor \& Epifanio 1985).

\section{DISCUSSION}

\section{Field distributions}

Earlier investigations on the east coast of the USA have shown that fiddler crab larvae are not retained in marsh creeks adjacent to adult habitat, but rather are transported seaward into primary estuaries (Dittel \& Epifanio 1982, Lambert \& Epifanio 1982). Our results suggest that after larvae enter the primary estuary there is a general upward shift in their vertical distribution during flood tides and a downward shift during ebb tides. Such a tidally rhythmic change in vertical distribution should promote retention of larvae in the estuary, and indeed all 5 zoeal stages commonly occurred at the bay mouth in our study. While statistical analysis showed a significant tidal change in the vertical distribution of larvae in the bay mouth, substantial numbers were collected at both surface and bottom regardless of tidal stage. This is perhaps explained as rhythmic vertical migration of the larvae modified by turbulent tidal mixing. In this case vertical migration would augment retention while tidal mixing would promote flushing. This is consistent with the observed occurrence of larvae in the bay mouth and on the adjacent continental shelf where results have shown that Uca spp. zoeae are an abundant component of the seasonal, neretic zooplankton. 


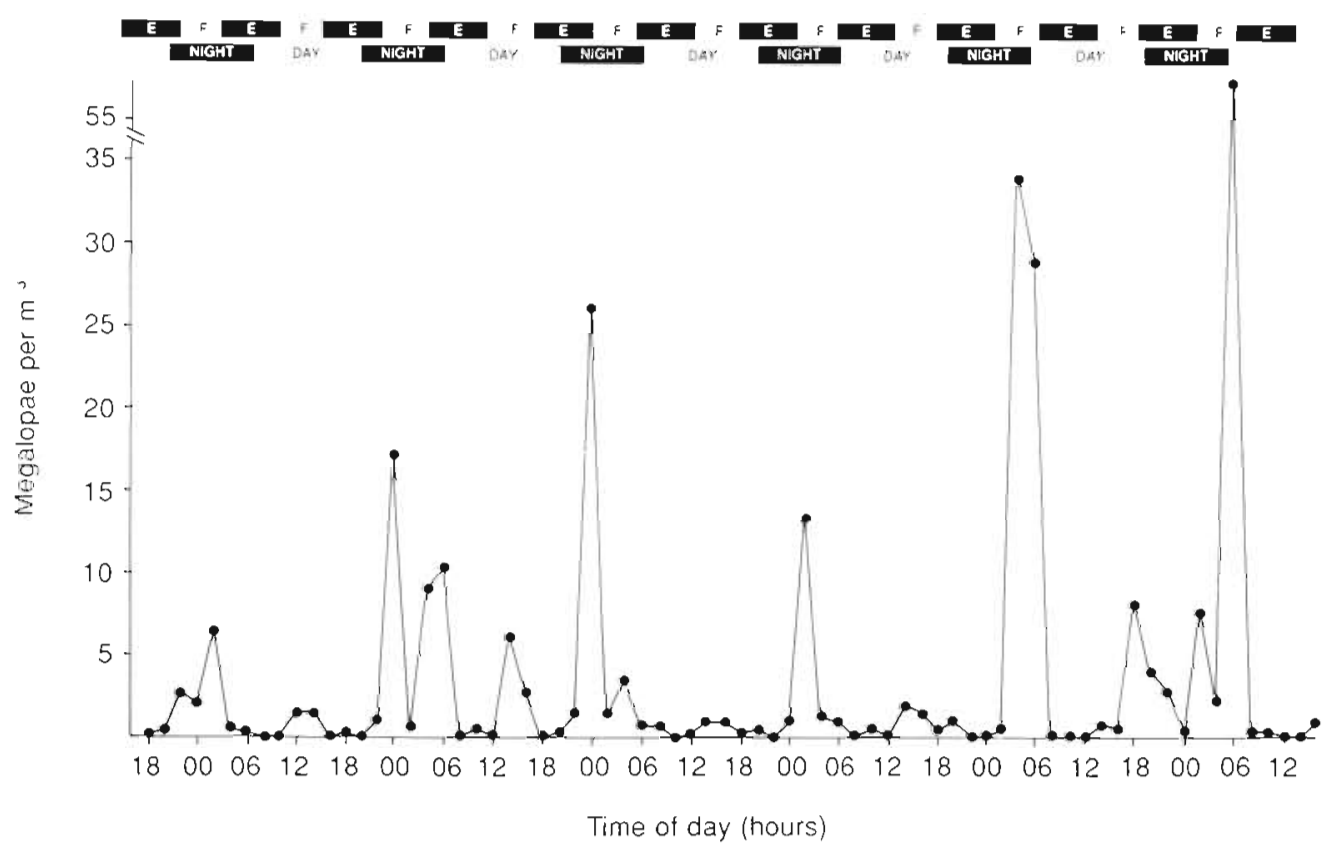

Fig. 6. Uca spp. Abundance of megalopae collected from $1 \mathrm{~m}$ beneath the surface on 6 to 12 Sep. 1985 in the Broadkill River near the mouth of Delaware Bay, USA. E: ebbing tidal current; F: flooding tidal current

Table 2. Uca spp. Effect of salinity on survival of zoea larvae cultured at constant salinity from hatching to the megalopa stage and on to crab Stage 1. Values for percentage survival to the megalopa stage were based on the number of newly hatched zoea larvae $(N=150)$ placed in each salinity at the beginning of the experiment. Values for percentages survival to crab Stage 1 were based on the number of zoea larvae that survived to the megalopa stage. U. pugnax was not tested at $10 \%$. Significant difference in mean values (ANOVA; $\alpha=$ $0.05)$

\begin{tabular}{|c|c|c|c|}
\hline \multirow[t]{2}{*}{ Species } & \multicolumn{3}{|c|}{ Salinity } \\
\hline & $10 \%$ & $20 \%$ & $30 \%$ \\
\hline \multicolumn{4}{|l|}{ Uca minax } \\
\hline Megalopa & $19.3(19.4)$ & 46.7 (23.5) & $48.7(17.7)^{\circ}$ \\
\hline Crab 1 & $25.6(36.4)$ & $4.9(10.5)$ & $3.6(7.6)^{\circ}$ \\
\hline \multicolumn{4}{|l|}{ Uca pugnax } \\
\hline Megalopa & - & $34.0 \quad(19.9)$ & $53.3(19.9)^{\bullet}$ \\
\hline Crab 1 & - & $10.9(14.5)$ & $9.4 \quad(12.7)$ \\
\hline
\end{tabular}

Table 3. Uca spp. Effects of salinity on survival of fiddler crab megalopae. Values are percentage of the initial number of megalopae (95 to 100 at each salinity) surviving to crab Stage 1. - Significant difference in mean values (ANOVA; $\alpha=0.05$ )

\begin{tabular}{|lcrl|}
\hline Species & \multicolumn{4}{c}{ Salinity } \\
& $10 \%$ & $20 \%$ & $30 \%$ \\
\hline Uca minax & $8.4(13.8)$ & $4.2(8.4)$ & $0.0^{\circ}$ \\
Uca pugnax & $4.0(8.2)$ & $11.0(16.5)$ & $1.1^{\circ}(4.6)$ \\
\hline
\end{tabular}

Shelf stations in the present investigation were located along the ancestral Delaware River channel, the path of maximum surface outflow from Delaware Bay (Pape \& Garvine 1982). All zoeal stages occurred at each station, but zoea Stages IV and $V$ were much more common at the 2 seaward stations. Available data on rates of zoeal development $\left(O^{\prime}\right.$ Connor \& Epifanio 1985) and non-tidal flow out of the bay (Pape \& Garvine 1982) suggest that zoeae collected along that transect originated in Delaware Bay. Some of these larvae may be carried back to the bay in the deep-water circulation, as the relative abundance of zoeae in near-bottom waters increased as larval development progressed. However, in situ determinations made coincidently with larval collections showed a strong thermocline at the 2 offshore stations with bottom temperatures below $15^{\circ} \mathrm{C}$. It is not known whether fiddler crab zoeae can survive temperatures this low, but at the least, developmental rates would be greatly retarded. This could delay molting to the megalopa stage until the larvae had been carried closer to the bay mouth. Those $U_{C a}$ zoeae remaining in near-surface waters would be carried farther south away from the bay mouth (Pape \& Garvine 1982) unless they were entrained in winddriven counter (northward flowing) circulation as hypothesized for the retention of blue crab zoeae in the shelf region adjacent to the bay mouth (Epifanio et al. 1984, D. R. Johnson 1985).

Larvae that molt to the megalopal stage on the continental shelf offshore of the Delaware estuarine circulation may be transported to other estuaries farther south 
(Pape \& Garvine 1982), while those molting within the area of estuarine influence of Delaware Bay appear to take advantage of tidal currents to accelerate their upstream transport. Megalopae in the Braodkill River were much more abundant near the surface during periods of nocturnal flooding tidal currents and apparently deeper in the water column during ebbing periods. In addition, megalopae in the Broadkill were an order of magnitude more concentrated 110 to 60 $\mathrm{m}^{-3}$ ) than Stage IV and V zoeae in the bay mouth or on the shelf. Because our determinations of zoeal and megalopal abundance were made during different years, we cannot discount the possibility of interannual variation in zoeal survival as an explanation. However, increased concentration of the megalopal stage has been reported before (Dittel \& Epifanio 1982) and may be due to swarming (or schooling) behavior on the part of the megalopae.

\section{Larval development}

Our results have shown that zoeae of Uca minax are notably more euryhaline than zoeae of $U$. pugnax. However, this seems to be in response to the low salinity in which $U$. minax eggs are incubated and hatched, as there is no retention of $U$. minax zoeae in marsh creeks adjacent to adult habitat (Lambert \& Epifanio 1982). In the present study, zoeae of both species showed higher survival at salinities typical of the primary estuary.

In contrast more $U$. minax megalopae metamorphosed to crab Stage 1 at the low salinity typical of adult habitat. This was the case whether the larvae were exposed to low salinity throughout zoeal development or only during the megalopal stage. $U$. pugnax megalopae appeared to be more euryhaline than $U$. pugnax zoeae, as larvae first exposed to low salinity during the megalopal stage were capable of metamorphosis. Nevertheless, $U$. pugnax megalopae generally fared better at higher salinities typical of their adult habitat. The low survival of $U$. pugnax first exposed to $30 \%$ during the megalopa stage corroborated the findings of O'Connor \& Epifanio (1985), but may have been an artifact, as unpublished results of similar experiments in our laboratory have shown survival comparable to that at $20 \%$. In the present study, megalopal survival was nearly identical at 20 and $30 \%$ for larvae reared in each salinity from hatching

\section{Conceptual dispersal - recruitment model}

It is possible to construct a simple scenario for the dispersal and recruitment of Uca spp. using estimates for residual and tidal currents of the Delaware Bay, its secondary estuaries, and the adjacent shelf (Dewitt \& Daiber 1973, Pape \& Garvine 1982). Residual flow is comprised of the gravitational flow of an estuary, the rectified tidal flow, and wind stress. While the residual flow of the Delaware system can be influenced by wind events of up to a week in duration (Wong \& Garvine 1984), the bay is generally classified as a partially mixed estuary where mean surface flow is seaward and mean bottom flow is landward. Entrainment of bottom waters from the shelf into the system extends at least $40 \mathrm{~km}$ seaward of the mouth, and general surface flow on the adjacent shelf is southerly due partly to Coriolis force (Pape \& Garvine 1982).

As adult females release larvae during nocturnal spring high tides, surface-dwelling early stages are flushed from secondary estuaries and tidal creeks. Subtidal currents in secondary Delaware estuaries such as the Broadkill River are on the order of $13 \mathrm{~km} \mathrm{~d}^{-1}(15 \mathrm{~cm}$ $\mathrm{s}^{-1}$ ) seaward at all depths (Dewitt \& Daiber 1973), so Uca zoeae are transported from the tidal creeks into the main estuary in 1 to 2 tidal cycles. Here in higher salinity waters, survival is increased and developmental rate accelerated (O'Connor \& Epifanio 1985, this study).

As mean residual surface velocity in Delaware Bay is $3 \mathrm{~km} \mathrm{~d}^{-1}$ seaward, zoeae released in tidal creeks near the mouth of the bay reach the bay mouth in 2 to $3 \mathrm{~d}$ after hatching. In spite of the fact that these larvae appear to undergo tidally rhythmic vertical migration, many zoeae are carried from the bay and entrained in the circulation of the adjacent continental shelf where they complete development to the megalopa stage (Christy \& Stancyk 1982, D. F. Johnson 1985). In the Delaware system, estuarine circulation extends about $40 \mathrm{~km}$ seaward of the bay mouth (Pape \& Garvine 1982), and any zoeae transported beyond must depend on wind-driven circulation for return to the parent estuary (D. R. Johnson 1985).

Megalopae retained in the estuarine-shelf circulations invade the estuary by active upward vertical swimming during flood tides (Meredith 1982, this study) or in combination with an initial short period of passive transport in residual bottom currents. For the adjacent continental shelf and Delaware Bay, a reasonable estimate for flooding velocity is 0.5 to $1.0 \mathrm{~m} \mathrm{~s}^{-1}$ (Pape \& Garvine 1982). During ebb tides, megalopae settle on the bottom to avoid seaward flushing. Because megalopae are most commonly found in the water column during nocturnal flood tides (Christy 1982, Brookins \& Epifanio 1985), they are transported towards the bay and upstream during nocturnal flood tides at 11 to $22 \mathrm{~km}$ per flood tide. In Delaware Bay this results in the advection of megalopae across the range of adult $U_{C a}$ habitats in 7 to $14 \mathrm{~d}$. 
As megalopae are transported upstream, they encounter lower salinity, which has an effect on development and survivorship to first crab $\left(\mathrm{O}^{\prime}\right.$ Connor 1982, this study). High salinity in the lower estuary appears to inhibit devlopment of Uca minax megalopae, while augmenting the process in $U$. pugnax (Tables 2 and 3). Thus our model predicts differential metamorphosis in the lower estuary with more $U$. pugnax surviving to the first crab stage. In contrast the low salinity of the upper estuary yiels increased mortality of $U$. pugnax megalopae with increased survival of U. minax.

The final reinvasion of tidal creeks and marshes brings megalopae to adult habitats. In the Broadkill River, for example, there are extensive adult populations of Uca minax and U. pugnax segregated into lowsalinity and high-salinity areas of the fringing marhes (Miller \& Maurer 1973). The Broadkill is typical of the secondary estuaries along the western shore of Delaware Bay in that it has a sharp salinity gradient with (tidal) fresh water occurring within $20 \mathrm{~km}$ of the river mouth. Reinvasion of the tidal creeks depends on upward migration primarily during flood tides. As average flood velocity is approximately $15 \mathrm{~cm} \mathrm{~s}^{-1}(13 \mathrm{~km}$ flood ${ }^{-1}$ ), megalopae are transported across the entire range of adult habitats in 2 tidal cycles. Because this amount of time is small compared to laboratory-determined megalopal durations (Wheeler 1978, O'Connor \& Epifanio 1985, this study), the effect of salinity on development of megalopae to crab Stage 1 is not important in separation of the 2 species into appropriate adult habitat within a given tidal creek. It is not clear whether this ultimate separation of $U$, minax and $U$. pugnax can be attributed to active selection of final habitat (e.g. differential stimulation of metamorphosis by biological or chemical characteristics of each habitat) or whether megalopae settle randomly in a given marsh with differential post-settlement mortality. It is quite clear, however, that salinity acts as only a gross filter in the separation of the 2 species along the primary estuary.

\section{CONCLUSIONS}

In general, mortality of larval forms of any marine organism can be ascribed to 1 of 3 categories; (1) advection away from suitable adult habitat; (2) starvation; or (3) predation. In the preceding discussion we have concentrated on the problem of advection because it is inconsequential that a larva is well fed and escapes predation if it is carried away from habitat suitable for adult existence. For organisms whose adult habitat is invariably found within an estuary, the risk of advection of larvae out of an estuary would appear to exert selective pressure for adaptations resulting in retention of larvae in the estuary. In contrast, Strathmann (1982) has argued that mortality factors such as predation and starvation are more intense in the estuarine than shelf environment, thus providing selective pressure for non-retentive dispersal strategies in estuarine species.

Conceivably, it is in response to these opposing selective pressures that estuarine species of crab show great differences in the degree of retention of their zoeal larvae. Three taxa of interest in the Middle Atlantic Bight are the mud crab Rhithropanopeus harrisï, the fiddler crabs Uca spp, and the blue crab Callinectes sapidus. Adult habitat of each of these species ranges into the upper estuary, nearly to fresh water. In spite of this, patterns of dispersal and recruitment differ greatly among the species. $R$. harrisii zoeae appear to be largely retained in the vicinity of adult habitat throughout 2 wk of zoeal development (Cronin 1982). R. harrisii larvae are relatively large with unusually long rostral and dorsal spines that may function as antipredation devices (Morgan 1981). In comparison Uca spp. larvae are small with reduced spination. Uca spp. zoeae are routinely flushed from oligohaline and mesohaline tidal creeks and develop in the primary esturary and on the adjacent continental shelf (Lambert \& Epifanio 1982). While C. sapidus females mate in upper estuarine areas, they migrate to the estuarine mouth where newly hatched zoeae are carried to the adjacent continental shelf and 3 to $4 \mathrm{wk}$ of zoeal development ensue (Epifanio et al. 1984). C. sapidus larvae are also small with reduced spination.

The facile explanation for these marked differences lies in the respective osmoregulatory capacities of the zoeae. Callinectes sapidus zoeae require high salinity water for successful development (Costlow \& Bookhout 1959); Uca pugnax larvae zoeae develop at salinities half that of seawater (O'Connor \& Epifanio 1985); and U. minax and Rithropanopeus harrisii are capable of developing at salinities below $10 \%$ (Costlow et al. 1960, this study). However, we might reasonably assume that all 4 species evolved from fully marine, stenohaline forms and that osmoregulatory capabilities were obtained along with invasion of the estuarine habitat. Indeed the adult form of each species demonstrates remarkable osmoregulatory capabilities, and there appears no reason a priori why osmoregulation could not have evolved in the larval forms if this trait were selectively advantageous.

Why, then, is Rithropanopeus harrisii the only one of these species that has evolved the combination of morphological, physiological and behavioral adaptations that allows a high level of retention? Perhaps the retentive strategy seen in $R$. harrisii evolved in response to the small size and low fecundity of the species, i. e., $R$. 
harrisii produces relatively few eggs per female and cannot afford much loss of larvae to advective physical processes (Strathmann \& Strathmann 1982). In contrast, fecund species like UCa spp. and Callinectes sapidus may be able to withstand greater advective loss. Thus it may be selectively advantageous for them to export their larvae to the primary estuary and on the neritic continental shelf where biological conditions may be more favorable.

Acknowledgements. This research was sponsored by NOAA Office of Sea Grant, Department of Commerce, under Grant No. NA85AA-D-SG033 (Project NO. R/M-4). We thank Meo Curtis, Mona DeVries, Nancy O'Connor, Christopher Valenti, and Capt. Thomas White for help in collection and analysis of plankton samples

\section{LITERATURE CITED}

Brookins, K. G., Epifanio, C. E. (1985). Abundance of brachyuran larvae in a small coastal inlet over six consecutive tidal cycles. Estuaries 8: 60-67

Christy, J. H. (1982). Adaptive significance of semilunar cycles of larval release in fiddler crabs (genus $U c a$ ): test of an hypothesis. Biol. Bull. mar. biol. Lab., Woods Hole 163: $251-263$

Christy, J. H., Stancyk, S. E. (1982). Timing of larval production and flux of invertebrate larvae in a well-mixed estuary. In: Kennedy, V. (ed.) Estuarine comparisons. Academic Press, New York, p. 489-503

Costlow, J. D., Bookhout, C. G. (1959). The larval development of Callinectes sapidus $\mathrm{R}$. reared in the laboratory Biol. Bull. mar. biol. Lab., Woods Hole 116: 373-396

Costlow, J. D., Jr, Bookhout, C. G., Monroe, R. (1960). The effect of salinity and temperature on larval development of the crab Rhithropanopeus harrisii (Gould). I. The effect of salinity and temperature on larval development. Physiol. Zool. 39: 81-100

Cronin, T W. (1982). Estuarine retention of larvae of the crab Rhithropanopeus harrisii. Estuar. coast. Shelf Sci. 15: 207-220

DeWitt, P., Daiber, F. C. (1973). The hydrography of the Broadkill River estuary, Delaware. Chesapeake Sci. 14: $28-40$

Dittel, A. I., Epifanio, C. E. (1982). Seasonal abundance and vertical distribution of crab larvae in Delaware Bay. Estuaries 5: 197-202

Epifanio, C. E., Valenti, C. C., Pembroke, A. E. (1984). Dispersal and recruitment of blue crab larvae in the Delaware Bay, USA. Estuar. coast. Shelf Sci. 18: 1-12

Heinle, R. R. (1965). Screen for excluding jellyfish and ctenophores from Clarke-Bumpus plankton samplers Chesapeake Sci. 6: 231-232

Johnson, D. F. (1982). A comparison of recruitment strategies among brachyuran crustacean megalopae of the York River, lower Chesapeake Bay and adjacent waters. Doctoral dissertation, Old Dominion Univ., Norfolk

Johnson, D. F. (1985). The distribution of brachyuran crustacean megalopae in the waters of the York River, lower Chesapeake Bay and adjacent shelf: implications for recruitment. Estuar. coast. Shelf Sci. 20: 693-705

Johnson, D. R. (1985). Wind-forced dispersion of blue crab larvae in the Middle Atlantic Bight. Continental Shelf Res. 4: 733-745

Lambert, R., Epifanio, C. E. (1982). A comparison of dispersal strategies in two genera of brachyuran crab in a secondary estuary. Estuaries 5: 182-188

Meredith, W. A. (1982). The dynamics of zooplankton and micronekton community structure across a salt-marsh estuarine interface of lower Delaware bay. Doctoral dissertation, Univ. of Delaware, Newark

Miller, K. G., Maurer, D. (1973). Distribution of the fiddler crabs. Uca pugnax and UCa minax, in relation to salinity in Delaware rivers. Chesapeake Sci. 14: 219-221

Morgan, S. G. (1981). Larval spines as an anti-predatory device in Rhithropanopeus harrisii (Decapoda, Xanthidae). Am. Zool. 21: 1004

O'Connor, N. J. (1982). The influence of salinity discontinuities on the swimming behavior of larvae of the fiddler crab Uca pugnax (Smith). M. S. thesis. Univ. of Delaware, Newark

O'Connor, N. J., Epifanio, C. E. (1985). The effect of salinity on the dispersal and recruitment of fiddler crab larvae. J. crust. Biol. 5: 137-145

Pape, E. H. III, Garvine, R. W. (1982). The subtidal circulation in Delaware Bay and adjacent shelf waters. J. geophys. Res. 87: 7955-7970

Sandifer, P. A. (1973). Distribution and abundance of decapod crustacean larvae in the York River estuary and adjacent lower Chesapeake Bay, Virginia. Estuar. coast. mar. Sci. 3: 269-279

Sandifer, P. A. (1975). The role of pelagic larvae in recruitment to populations of adult decapod crustaceans in the York River estuary and adjacent lower Chesapeake Bay, Virginia. Estuar. coast. mar. Sci. 3: 269-279

Strathmann, R. R. (1982). Selection for retention or export of larvae in estuaries. In: Kennedy, V. (ed.) Estuarine comparisons. Academic Press, New York, p. 521-537

Strathmann, R. R., Strathmann, M. F. (1982). The relationship between adult size and brooding in marine invertebrates. Arn. Nat. 119: 91-101

Wheeler, D. (1978). Semilunar hatching periodicity in the mud crab Uca pugnax (Smith). Estuaries 1 268-269

Wong, K. C., Garvine, R. W. (1984). Observations of windinduced, subtidal variability in the Delaware Estuary. J. geophys. Res. 89: 10 589-10 597 